\title{
9 Split-screen visions: Heracles on top of Troy in the Casa di Octavius Quartio in Pompeii
}

\author{
KATHARINA LORENZ
}

The houses of Pompeii are full of mythological images, several of which present scenes of Greek, few of Roman epic. ${ }^{1}$ Epic visions, visual experiences derived from paintings featuring epic story material, are, therefore, a staple feature in the domestic sphere of the Campanian town throughout the late first century BCE and the first century CE until the destruction of the town in $79 \mathrm{CE}$. The scenes of epic, and mythological scenes more broadly, profoundly undercut the notion that such visualisations are merely illustration of a textual manifestation; on the contrary: employing a diverse range of narrative strategies and accentuations, they elicit content exclusive to the visual domain, and rub up against the conventional, textual classifications of literary genres.

The media- and genre-transgressing nature of Pompeian mythological pictures renders them an ideal corpus of material to explore what the relationships are between visual representations of epic and epic visions, what characterises the epithet 'epic' when transferred to the visual domain, and whether epic visions can only be generated by stories which the viewer associates with a text or texts of the epic genre. One Pompeian house in particular provides a promising framework to study this: the Casa di Octavius Quartio, which in one of its rooms combines two figure friezes in what is comparable to the modern cinematographic mode of the split screen. Modern study has been reluctant to discuss these pictures together, ${ }^{2}$

${ }^{1}$ Vitruvius (7.5.2) differentiates between divine, mythological and Homeric decorations, emphasising the special standing of Iliad and Odyssey in comparison to the overall corpus of mythological depictions; cf. Croisille 2005: 154.

2 Aurigemma 1953 [Iliad], Croisille 1985 [Heracles] and Coralini 2001a/2001b [Heracles] each discuss only one of the two friezes; Brilliant 1984: 61 simply asserts the 'subordination of the Iliac Frieze to the elaborate program of Heraclean subjects'. Only John Clarke aimed towards a combined analysis, tracing the steps of a viewer of the two friezes during a dinner party. But while his observation that the design of the two friezes responds to the arrangement of the dining couches set up in this room (Clarke 1991: 206-7), and his assessment of how the viewers would have to supplement knowledge while moving from one picture to the next, present a refreshing attempt at studying the two friezes together, his adoption of Karl Weitzmann's notion of epitomized narrative curtails the opportunity to investigate the particular visual potential of the combination and the visual narrative that ensues from it (Clarke 1991: 203-7, Weitzmann 1970: 12-46): he can only point out which scenes are depicted together, without exploring the 
yet it is the interaction of the two friezes which yields important insights into the visualisation of epic in the second half of the first century CE.

\section{The Casa di Octavius Quartio (Regio II 2.2)}

The Casa di Octavius Quartio epitomises the Pompeian epic at large: the extensive complex that in its preserved dimensions came into being after the earthquake of $62 \mathrm{CE}$ has played the lead in various seminal studies on living in the Roman domestic context, prominently in Paul Zanker's 1979 article, in which he used it as the central example to demonstrate that Pompeian houses were in the Imperial period designed on the basis of a construction kit inspired by much larger Roman country villas, layering water features and landscape vistas with picture and sculpture galleries even in the most restricted space. ${ }^{3}$

The domestic section of the Casa di Octavius Quartio only takes up a quarter of the whole dwelling but packed into it is a range of spaces more characteristic of larger houses, here scaled down to fit: the viridarium (g) with the vast garden space (l) to its rear has every pretension to appear as a full-blown peristyle. In this, it is supported by the Canopus and Euripus waters, which in their t-shaped arrangement form the key features of the garden. They allude to a lavish park landscape, while giving structure to the house and its agricultural component: they provide a picturesque setting for the sumptuous, even if petite, outdoor dining area, the biclinium (k); and, in a more practical function, they house a fish farm and feed the extended orchard that takes up most of the garden space (Figure 9.1). ${ }^{4}$

Whilst this layout points to a socially aspiring member of the Pompeian middle classes as owner of the house, further evidence to identify him is not conclusive: based on a set of electoral inscriptions on the external walls, the complex was initially attributed to a certain Loreius Tiburtinus. ${ }^{5}$ Then, a seal found in cubiculum (3) introduced the name by which the house is known today: Octavius Quartio, a character about whom nothing else is

impact of such combinations beyond the observation that there exist specific formal parallels between the friezes.

3 Zanker 1979. On the house in general: PPM III 1991: 42-108, Spinazzola 1953: 1026-7.

4 Zanker 1979: 471-2, Clarke 1991: 23-5.

5 Some scholars see this name also supported in the labelling of the Isis priest on the south wall of Room (f) as Amulius Faventinus Tiburs: PPM III 1991: 77, no. 52. 


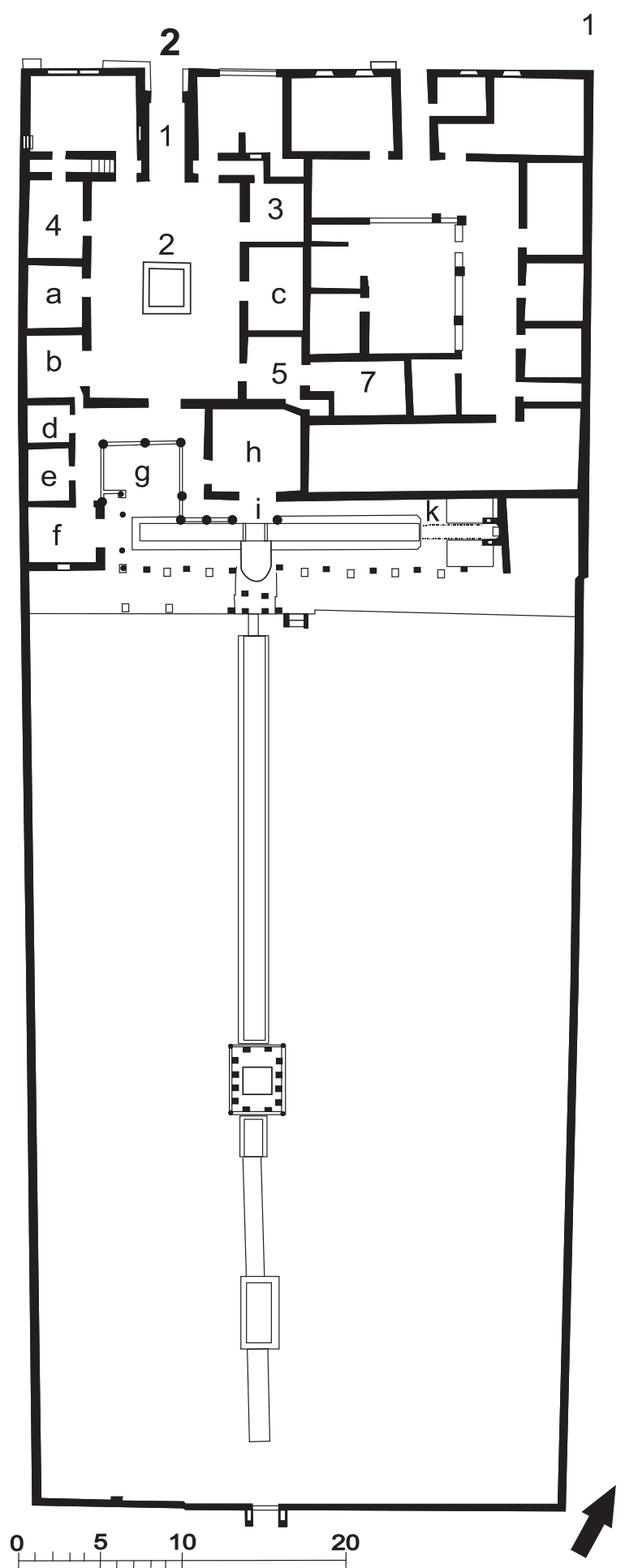

Fig. 9.1 Pompeii, Casa di Octavius Quartio (II 2,2). Scale in metres. 
known. ${ }^{6}$ The name of the house, therefore, while establishing a false sense of familiarity, provides no clear-cut answers to questions concerning the conceptual origin or impact of the house's design and decor.

This situation is characteristic for most Pompeian houses, and has led to scholars using the interior decoration as an indirect means of establishing the owner's mentality and so his persona. The Casa di Octavius Quartio offers a remarkable dataset in this regard: the striking Fourth-Style paintings, part of the post-earthquake redecoration campaign, stand out because of their content and their interplay with the sculpture display in the Canopus area, and because they are signed by the painter. ${ }^{7}$ This is the only occurrence of an artist's signature in Pompeii and, therefore, documents at best some confidence behind the pictorial design, and at least the wish to buy into a label that might have indicated a certain taste; in either case the signature can be read as an indicator of the high aspirations of both artist and commissioner.

Other elements of the decoration have been used to establish a more tangible identification of the owner, yet these efforts only yield circumstantial argument: Mariette de Vos took a painted corona civica over the main entrance as evidence that the owner was an Augustalis. ${ }^{8}$ Others have tried to forge a connection between the owner and the cult of Isis, based on the interior decoration of Room (f) with its depiction of a priest of Isis by the name of Amulius Faventinus Tiburs and the sculptural display in the garden. ${ }^{9}$

This is not the place to assess the plausibility of such attributions. But it would be a mistake to assume that the vision behind the decoration, and with it any claims about the owner, could be sustained on the basis of such detached observations. That would undervalue the complexity of the decoration, and it would disregard the fact that it is precisely in the interaction of individual decorative elements that the design of this house realises its power.

${ }^{6}$ Della Corte 1930 [Loreius Tiburtinus], Spinazzola 1953: 369 [Octavius Quartio]. See also Castrén 1975: 32, Zanker 1979: 470-1, Zanker 1998: 145-56, Söldner 2004: 206, Nappo 2007: $362-4$.

7 The signature is painted on one of the couches in biclinium (k). CIL IV 7535: Lucius pinxit. L. Richardson 2000: 147-53, Varone and Stefani 2009.

8 de Vos 1993: 87-8. This argument is also founded on the decorative parallels between what Pliny reports about the collection of Heracles paintings in the Augustan Porticus Octaviae and the decoration of Room (h). The analysis of the decoration in Room (h) below will demonstrate that even if similarities in the choice of topic existed they could not explain the intricate design in the Casa di Octavius Quartio, which was clearly geared to its own spatial and ideational requirements.

9 Della Corte 1930, de Vos 1980: 7 no. 6, Jashemski 1993: 238, Platt 2002a: 103-4. 


\section{Room (h)}

The heart of the Casa di Octavius Quartio, in terms of both its physical location and its role in visualising epic, is Room (h). Situated between the viridarium and the garden, the room is $25 \mathrm{~m}^{2}$ in size and can be accessed through two wide doorways (Figure 9.2). These open the view either into the viridarium or out on to the central axes of the garden, Euripus and Canopus. Its position and the large openings indicate that the room served as a reception and dining space, especially suited for summer events.

Decorated in the early 70s CE, ${ }^{10}$ the space displays a penchant for lavish luxury (Figure 9.3): ${ }^{11}$ the pavement includes a precious marble roundel in its centre, the lower parts of the walls are painted to evoke slabs of expensive coloured marble and the vaulted ceiling was once elaborately stuccoed. ${ }^{12}$ Adding to this atmosphere of expensive, albeit ersatz, venerability are the two friezes occupying the middle zone of the four walls of the room, interrupted only by the door openings. ${ }^{13}$ Each covering $18 \mathrm{~m}$, the upper frieze contains eight episodes from the life of Heracles, the lower shows fourteen episodes from the Iliad (Figure 9.4).

Despite their poor preservation (the decoration of the north wall is missing almost in its entirety, and there exist considerable lacunae on the other three walls), each frieze displays distinct qualities, differing from its partner in height, background colour and spatial composition. The Iliad frieze is only $30 \mathrm{~cm}$ in height and has bright figures set in front of a dark background. With the characters acting on a small band of ground that reaches into the space behind, most of the frieze space is left to detailed renderings of landscape settings and further groups of figures in the background, diminished in size to indicate distance. This perspectival alignment towards the back, extending the pictorial space

10 Schefold 1988: 196 dates it to around 75 CE.

11 On the room and its decoration: Brilliant 1984: 60, Clarke 1991: 201-7, de Vos 1993, Ling 1995, Coralini 2001b.

12 PPM III 1991: 98-9, no. 85. On the use of faux-marble in Pompeii: Eristov 1979, Leach 2004: 174, Fant 2007.

13 On the basis of stylistic comparison with the signed decoration in biclinium (k), Richardson has suggested that the figural decoration of this room was also done by the painter Lucius (L. Richardson 2000: 147-53, esp. 149-50 and 151). This would make this painter a true jack of all trades, well versed in painting mythological panels, animal megalographic and different types of continuous friezes. If this was correct, it would have considerable repercussions for our understanding of the production processes in Roman painter workshops. See Strocka 2007: 304 with further bibliography. 


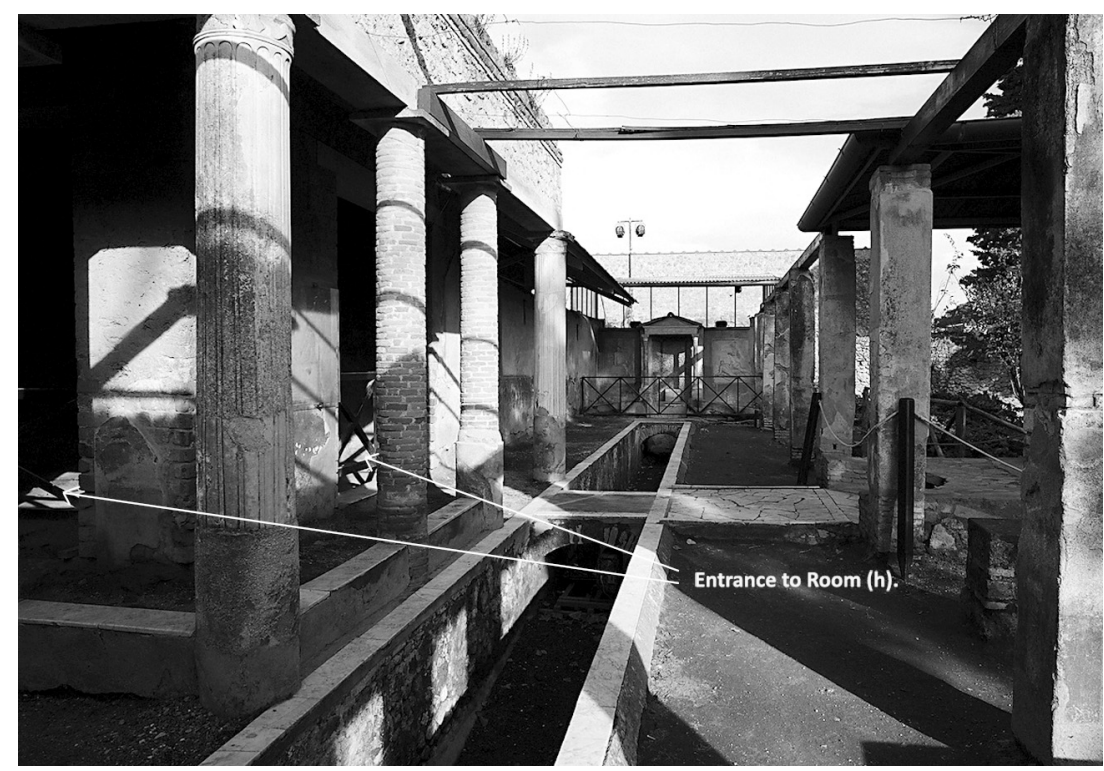

Fig. 9.2 Pompeii, Casa di Octavius Quartio (II 2,2). Euripus area with entrances to $\operatorname{Room}(\mathrm{h})$.

into the wall, is a characteristic of decorations of the Second Style, in fashion in the latter decades of the previous century. ${ }^{14}$

In contrast, the figures of the Heracles frieze above appear to progress forward, into the actual space in front of the picture, as is a common feature of contemporary Fourth-Style decorations: considerably taller than the one below at $80 \mathrm{~cm}$, this frieze is rendered in lighter colours and dominated by figures and their actions. With layers of bodies overlapping each other, intersected by columns to separate individual scenes and framed by a thick curtain above and in the corners, the depiction exudes spatial qualities, but of a kind to reiterate the physical framework of the room: the bodies in the background serve as a barrier against attempts at generating illusionistic openings; only the segment on the west wall displays vistas to reach further into the depth of the frieze. ${ }^{15}$

14 Karl Schefold rightly characterised the Iliad frieze as set between the more cursory depictions in the frieze from the Casa del Criptoportico and those landscape vistas that make the Esquiline frescoes, featuring the Odyssey (Schefold 1988: 197). See Lorenz forthcoming b.

15 Schefold 1988: 196 uses these compositional features to relate the frieze to a Greek original of the later fourth century BCE and links it stylistically to a painting by Artemon that showed Stratonike I, the wife of Antiochus I (324-261 BCE), on which Pliny reports (HN 35.140). 


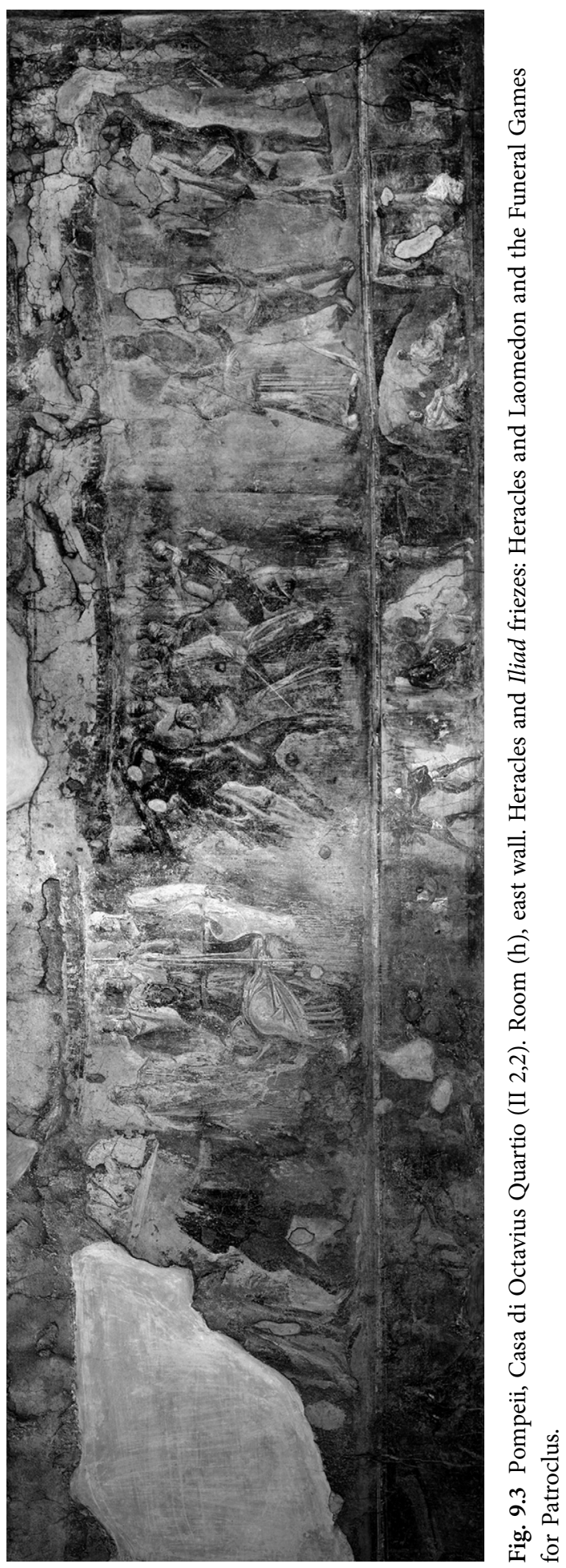




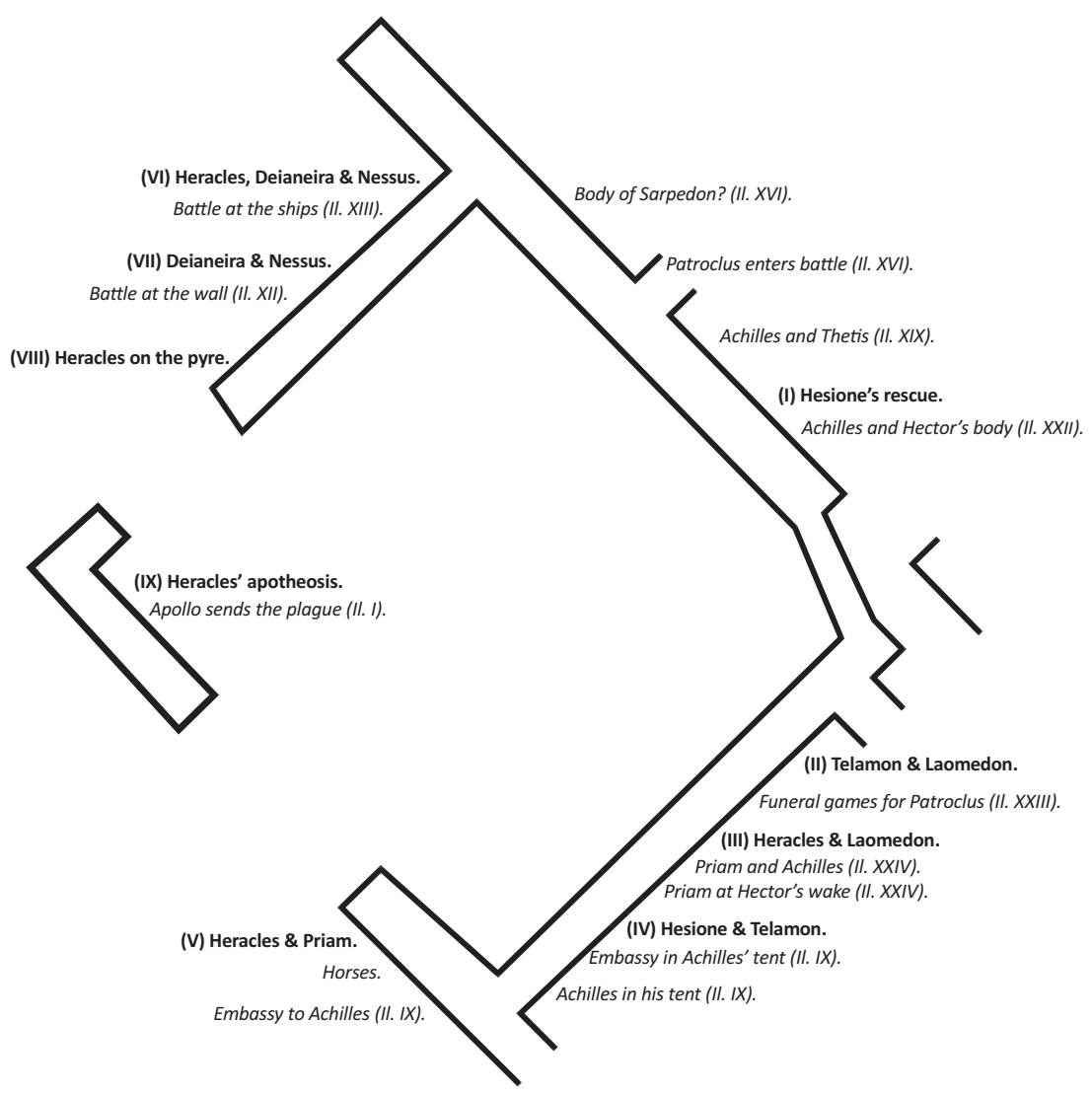

Fig. 9.4 Pompeii, Casa di Octavius Quartio (II 2,2). Room (h), overview of episodes.

The competing characteristics of the two friezes, the different concepts of technical space employed, their stylistic heritage, size and dominating colours, find correspondence in the overall design of the walls: the predominantly lightly coloured faux-marble orthostates below, reminiscent of the Second Style and posing as the weighty foundation of the whole, are in sharp contrast to the typical Fourth-Style filigree embroidery borders and tender vegetal elements on dark ground that adorn the upper zone. But in spite of this flamboyant assortment of individual features, the room's wall decoration still comes together to form an impressive whole: that is, a scaenae frons not unlike those that can be found in the Fourth Style in the Casa di Pinarius Cerealis (Regio III 4,4) and the Domus Aurea in Rome, with a socle of precious orthostates, above which the architecture rises. ${ }^{16}$

16 Moormann 1983, Leach 2004: 93-122. 
In contrast to these other contexts, however, the middle zone of the walls in Room (h) is not rendered as a stage, with architecture populated by characters, standing in doorways or peeping over parapets. Instead the architectural illusionism so characteristic of the Fourth Style is replaced here in the middle zone with an element seemingly diametrically opposed to a stage arrangement: a self-contained narrative frieze, or rather, two of them at that. Their presence dilutes the architectural materiality of socle and dado and renders them a supporting framework, a mere atmospheric quotation; a setting not unlike an old-fashioned theatre turned cinema, with the stage housing the screen.

This remarkable arrangement is matched by the content of what is depicted. Epic cycles such as the Iliad frieze feature on Roman walls predominantly in the Second Style, the stylistic class in which the small frieze in the Casa di Octavius Quartio formally belongs: ${ }^{17}$ the Second-Style decorations of the Casa del Criptoportico (Regio I 6,2) comprise more than eighty scenes from the Iliad and Aithiopis in the area responsible for the name of the house; ${ }^{18}$ the Odyssey landscapes from the Esquiline provide a striking example of the transformation of the Homeric epics, contemporary with the frieze in the Casa del Criptoportico; ${ }^{19}$ then, the frieze from the Villa in Terzigno outside Pompeii leaves behind the Homeric paradigm, but still keeps to epic material that during the late Republic and early Principate is featured embedded in the Iliad: ${ }^{20}$ that is, the life of Aeneas. ${ }^{21}$

In the Fourth Style, the stylistic class in fashion when the Iliad frieze was painted on the walls of Room (h), depictions of the Homeric epics take a differing guise: the stuccoed frieze in the Casa del Sacello Iliaco (Regio I 6,4) presents five individual episodes of the Iliad, without the same urge for comprehensiveness that characterises the design in the Casa del Criptoportico. $^{22}$ While formally adhering to the concept of a cyclical frieze, the rigorous selection of a few central scenes creates a prominent filter for the

17 The most comprehensive discussion of the three Pompeian Iliad friezes is still Aurigemma 1953. See also Bianchi-Bandinelli 1953, Andreae 1962, Blanckenhagen 1963, Weitzmann 1970: 17-33, Brilliant 1984: 59-60, Biering 1995, Wyler 2006.

18 Casa del Criptoportico (Regio I 6,2): PPM I 1990: 193-277; Brilliant 1984: 62-3, Mielsch 2002: 49-50.

19 Mielsch 2002: 50.

20 The link is extensively played out on some of the contemporary Tabulae Iliacae: see Squire in this volume.

21 Terzigno: Croisille 2005: 152-3, Strocka 2005-6. It is worth noting that in Room (h) it is the Iliad, not the Aeneid, which is by this time the Romans' epic of choice, which is combined with Heracles.

22 PPM I 1990: 280-329, Brilliant 1984: 63-4, Croisille 2005: 160. 
epic as a whole. This offers a far wider scope for establishing allegorical or abstract connections between the individual points of the epic than could be achieved in a frieze as literally continuous as the one in the Casa del Criptoportico.

This segmentation finds a precursor in the positioning of the Circe scene as the narrative hub of the Odyssey landscapes in the Second Style, notwithstanding the otherwise unambiguous claims of the design to visualise a continuous landscape. Depictions of scenes from the Iliad in Rooms (3) and (4) of the Domus Transitoria in Rome, probably of Claudian date, provide a more contemporary example of the selective approach towards epic material in Fourth-Style decorations; ${ }^{23}$ another, even later, example comes from the Temple of Apollo in Pompeii, decorated after the earthquake of $62 \mathrm{CE}^{24}$ The practice is matched by the presentation of wooden panel paintings in public buildings, such as the pictures of the Trojan War by the Greek painter Theorus in the Porticus Philippi in Rome, listed by Pliny. ${ }^{25}$

Such selection facilitates a zooming in on individual aspects of any given story and its characters, and it corresponds to the general development of the central mythological panels of Roman wall painting from the late Second Style onwards: ${ }^{26}$ three or four of these paintings are usually combined in a room, mostly derived from non-related storylines, freely mixing epic and non-epic mythological material, and generating a range of narrative and ideational relationships between the individual scenes. An example which contains elements of Homeric epic is the decoration of the late Third Style in Room (g) of the Casa degli Amorini Dorati (Regio VI 16,7.38), where scenes of Thetis and Hephaestus and Achilles and Briseis frame a panel on the central wall depicting Jason and Pelias. ${ }^{27}$ Mutual referentiality replaces the cyclic development which in the literary domain appears as the central feature of epic.

In the face of this development, the Iliad frieze in the Casa di Octavius Quartio represents an anachronism. ${ }^{28}$ In this it is copied by the Heracles frieze, which is without any template: while numerous individual

23 Domus Transitoria: LTUR II 1995: 199-202 [M. de Vos], L. Richardson 1992: 138-9. See also Croisille 2005: 165, Strocka 2007: 317.

24 Temple of Apollo (Regio VII 7,32): PPM VII 1997: 286-304.

25 Plin. HN 35.144. See Bianchi-Bandinelli 1955. ${ }^{26}$ Lorenz 2008: 28-41.

27 PPM V 778-91, figs. 122-3, 126-7, 130-1, Seiler 1992: 111-12, Lorenz forthcoming a.

28 Another Fourth-Style example shares an element of this anachronism of continuous narrative, but without opting for a frieze layout: the panels in ala (4) in the Casa del Menandro (Regio I 10,4), documenting the fall of Troy by juxtaposing scenes of Cassandra with the Trojan horse, Helen, Cassandra and Priam and the death of Laocoon: PPM II 277, 281-2, figs. 56, 62, 64. 
mythological panels present various episodes from the life of the hero from the late Second Style onwards, ${ }^{29}$ no other continuous frieze exists that combines events from his life. Even more tellingly, the frieze in Room (h) is the only one on Pompeian walls to celebrate an individual hero, and one whose exploits are not part of the Homeric epics. ${ }^{30}$ This corresponds with Heracles' ambiguous position with regard to literary genres overall: while his mythological resonance includes but goes far beyond epic, Heracles' life is not the central subject of any surviving epic, but known to us mainly through historical writing and tragedy. ${ }^{31}$ The Heracles frieze, therefore, translates its content into a visual format associated with an earlier decorative type and a different genre of visual narrative, notwithstanding its display of spatial properties characteristic of the Fourth Style.

A final peculiarity in the frieze decoration of Room (h) is the number of its name tags, otherwise unmatched in Pompeii, and the unique situation tag, 'LOIMOS', written into the scene of the Iliad frieze on the south-west wall and identifying it as a depiction of Apollo inflicting the plague upon the Achaean camp. The only Pompeian parallels, distant as they are, are the depictions of the Second Style in Room (y) of the Casa degli Epigrammi (Regio V 1,18), in which text and image go together to create entertaining riddles, ${ }^{32}$ and the depiction of Micon and Pero in the Fourth Style in Room (6) of the Casa di M. Lucretius Fronto (Regio V 4a), in which an epigram in the fresco rubs up against the scene on display. ${ }^{33}$

This survey demonstrates how unusual the two friezes are, individually and in combination. Elements from the life of Heracles obviously intersect with the story of Troy and, on rare occasion, are represented as such, for example in the Domus Transitoria where, among the other panels depicting episodes from the Iliad, one shows Heracles enabling the young Priam to take power. ${ }^{34}$ It is, however, the way in which the epic aura of the Iliad frieze in the Casa di Octavius Quartio permeates the life of Heracles, the non-epic component of the two friezes, which makes this combination

${ }^{29}$ Coralini 2001a.

30 Achilles is the only hero whose life, as part of the Iliad friezes, is visualised in extended fashion.

31 Apollod. Bibl. 2.4.8-8.5, Diod. Sic. 4.8-39, Eur. HF, Soph. Trach., Sen. Hercules furens and Hercules Oetaeus. Both Apollonius Rhodius and Valerius Flaccus in their respective Argonautica poems recount parts of Heracles' life in the context of epic; Ovid provides another account, related to the epic genre (Met. 9.1-272).

32 PPM III 1991: 539-73 [M. de Vos], Neutsch 1955, Strocka 1995, Bergmann 2007, Squire forthcoming $b$.

33 PPM III 1991: 966-1092, Lorenz 2008: 428.

34 LTUR II 1995: 201, de Vos 1990: 167-71, Coralini 2001a: 81. 
stand out, marking the latter as a promising starting point for an exploration of epic visualisations, despite, if not because of, its status as non-epic.

\section{The Heracles frieze}

Two different strands of Heracles' life are on display: the Iliadic cycle and the events leading to his death, all enriched by the surrounding decorative features usually understood as derived from the decorations of Hellenistic palaces, red curtains and columns. ${ }^{35}$ In literature, the Iliadic cycle includes the story of Laomedon, king of Troy, who refused to reward Apollo and Poseidon for the erection of the walls of his city. As punishment, Apollo sends the plague and Poseidon a kètos (sea monster) to ravish Laomedon's land, and the king seeks to appease the gods by offering his daughter Hesione as a sacrifice to the sea monster, chaining her to a cliff. On a contract with Laomedon, and with the horses of Tros as a promised reward, Heracles steps in to rescue Hesione. Laomedon, however, breaks his word anew, and so Heracles sets off to destroy Troy, arrange for Telamon to marry Hesione, ${ }^{36}$ and appoint the boy Priam to the Trojan throne. ${ }^{37}$

In Room (h), the Iliadic cycle stretches from the eastern part of the north wall down the whole of the east wall and ends on the eastern part of the south wall, taking its beginning with the rescue of Hesione in the northeast corner of the room (Figure 9.4). While nothing is preserved of this scene today except for a stretch of seashore depicted in the east corner of the north wall, ${ }^{38}$ the three scenes of Heracles' adventures at the court of Laomedon following on the east wall are the best preserved in the room, their development demonstrating that here key elements of Heracles' characterisation are delivered.

35 Picard 1970: 80-1 pl. 55, PPM III 1991: 84-91, nos. 64-5, 68-9, 72. Cf. the display of the megalographic frieze in the Villa of P. Fannius Synistor at Boscoreale: R. Smith 1994, Torelli 2003.

36 This is the version favoured by the Greek literary sources; in Etruscan iconography, Heracles is shown to marry Hesione himself (Coralini 2001a: 77).

37 Homer, Il. 5, 628-58, 14.250-66, 15.15-40; Coralini 2001a: 77-81, Jourdain-Annequin 1989: 457-9, 1996: 270, Woodford 1993: 46-51, 100-4, 127-9. Comparison between the Heraclean Ilioupersis and that of the Achaeans: Burkert 1998: 21, Wathelet 1998: 65-8.

38 Croisille 1985: 90, Clarke 1991: 204-5, Coralini 2001a: 169. Coralini argues against Clarke and Croisille, objecting to the former that the seashore on its own is not conclusive evidence for the existence of a liberation scene, and to the latter that it is unlikely that the rescue scene of Hesione would only have started on the east wall. 
Closest to the north-east corner, the hero and the king go head to head, to contest the reward for Hesione's rescue: ${ }^{39}$ Heracles, identified by the lionskin falling from his left arm, stands in contrapposto in front of Laomedon, his muscular and tanned body presented frontally towards the viewer. The bearded king sits on the right, dressed in long oriental garments and wearing a Phrygian cap, his status confirmed by the sceptre in his left. As an indication of the Trojan court, four oriental men stand behind him. The Trojans look towards Telamon, who is approaching from the direction of Heracles; the horses of Tros, his price for the rescue of Hesione, show their heads behind him.

In the scene following to the right, the static atmosphere gives way to a dynamic fight, with Heracles seeking retaliation from Laomedon (Figure 9.3). The rear view of the hero's massive body dominates the scene as he thrusts his club against the king. ${ }^{40}$ The latter is on his feet, identified once more by his sceptre, but notably characterised by cowardice: he does not defend himself but seeks cover behind a courtier, who in turn begs Heracles to retreat. ${ }^{41}$ Two men flee in panic, while a sizeable group of Trojans watches from the background.

The wedding of Hesione and Telamon in the next scene recovers a peaceful atmosphere (Figure 9.3): ${ }^{42}$ the bride is veiled, and husband and wife are shown in dextrarum iunctio. ${ }^{43}$ Heracles stands behind the two, much larger in size and dressed in a long garment, acting as a kind of priestly guarantor of their matrimonium. From here, the cycle steers towards its conclusion, first with an enigmatic scene, with a nude Heracles alone, again seen from behind, and adorned with his usual attributes, of bow and lionskin; then, in the east corner of the south wall, the investiture of young Priam as king of Troy ends the cycle, with the nude hero seated on a rock, placing a Phrygian cap on the head of the boy in front, who in turn holds a sceptre in his left. ${ }^{44}$

Pompeii yields few iconographic parallels for these scenes from the Iliadic cycle and their explicit focus on Heracles' role, first as negotiator, then as just avenger, and finally as master of religious and political ceremonies. Three episodes occur: events around the erection of the walls of Troy, not documented in what is extant in the Casa di Octavius Quartio, are thematised in

39 Croisille 1985: 90, Coralini 2001a: $169 . \quad{ }^{40}$ Croisille 1985: 90, Coralini 2001a: 170.

${ }^{41}$ Croisille 1985: 90 identified this figure as Hesione. $\quad{ }^{42}$ Coralini 2001a: 170.

43 RE XVII 1488 s.v. nuptiae [A. Ehrhard], RE XXIII 750-4 s.v. pronuba [S. Weinstock], Hamberg 1945: 26-27, Reekmans 1958, Kockel 1993: 49-50, Reinsberg 2006: 79-82.

44 Coralini 2001a: 171-2. 
two contexts across the Third and Fourth Style; ${ }^{45}$ the rescue of Hesione appears in five versions, all but one of them Third Style; ${ }^{46}$ and the appointment of Priam occurs twice in Pompeii, confined to the Fourth Style: while the remains of the picture in the Casa delle Nozze d'Argento (Regio V 2, i) present it as similar to the version in the Casa di Octavius Quartio, the version in the Casa del Naviglio (Regio VI 10,11) presents a less officious scene, with the boy Priam approaching the seated hero with open arms, being followed by his mother. ${ }^{47}$ The iconographic scope, therefore, confirms that the version in Room (h) is accentuated towards a more ceremonial atmosphere.

With the Pompeian evidence patchy, the closest parallel for a depiction of Heracles' Iliadic cycle is provided by a literary source: Pliny describes panel paintings by the Greek artists Artemon and Antiphilus, ${ }^{48}$ on display in a large exedra (schola Octaviae?) within the Porticus Octaviae in Rome. ${ }^{49}$ But while the passage documents the popularity of the topic in the Augustan period, Pliny keeps his report of the actual depictions terse as usual, and so his statement cannot be used to assess whether the decoration

45 The first, a panel of the early Third Style in the Casa del Citarista (Regio I 4,5.25), shows Apollo and Poseidon in front of Laomedon and his court, claiming their reward for the construction of the walls: MANN inv. no. 111 472; from Room (20), east wall. PPM I 1990: 151, no. 59, Strocka 2005-6: 95-8. The second, a panel of the Fourth Style in the Casa di Sirico (Regio VII 1,25.47), shows the gods during the actual construction: Room (10), west wall. PPM VI 1996: 294-6, figs. 117-19.

46 LIMC VIII 1 1994: 623-9 s.v. Hesione [J. Oakley], Brommer 1955: 142-8, Diez 1960, Lesky 1967, Croisille 1982, Schefold 1988: 190-8, Lindner 1994: 95-102, Coralini 2001a: 78-9, Hodske 2007: 173-4, Lorenz 2008: 135-7, 391-8. The myth is almost exclusively to be found in Roman art - the Pompeian pictures are Casa del Pane (Regio VIII 3,31), exedra 91; Third Style: PPM VIII 1998: 449-50, Dawson 1944: 108 no. 57, Coralini 2001a: no. P.097. Casa di M. Epidius Sabinus Regio (IX 1,22.29), room (10), west wall; Third Style: PPM VIII 1998: 994-5, fig. 67, LIMC VIII 1994: s.v. Hesione no. 10, Coralini 2001a: no. 106, Lorenz 2008: no. K65bW. Domus T. Dentatius Pantherae (Regio IX 2,15.16), atrium (d), east wall; Third Style: PPM IX 1999: 17, no. 26, LIMC VIII 1994: s.v. Hesione no. 1, Coralini 2001a: no. P.109, Lorenz 2008: no. K67bO. Casa del Centenario (Regio IX 8,3), peristyle (9), west wall; Fourth Style: PPM IX 1999: 972-3, fig. 130-1, Coralini 2001a: no. P.131, Lorenz 2008: no. K79aW. Merkelbach 1994: 85 could show that an early Third-Style fresco from Regio VI 17,10, previously identified as a depiction of Perseus and Andromeda (e.g. Schmalz 1989: passim), shows Heracles and Hesione (MANN Inv. no. 9443, H1184, LIMC I 1 1981: 778 no. 31 s.v. Andromeda [K. Schauenburg]). The same identification had been presented previously by Carl Robert.

47 LIMC IV 1 1988: s.v. Herakles 837 no. 1693, LIMC VII 1994: s.v. Omphale 47 no. 11, PPM IV 1993: 1098-9, fig. 46-7, Coralini 2001a: no. P.064. Casa delle Nozze d'Argento (Regio V 2, i), Room (q), east wall; Fourth Style: PPM III 1991: 676-772, Coralini 2001a: n. P.50; Ehrhardt 2004: 82. Casa del Naviglio (Regio VI 10,11), oecus (24), west wall; Fourth Style: LIMC IV 1 1988: s.v. Herakles 837 no. 1693, LIMC VII 1994: s.v. Omphale 47 no. 11, PPM IV 1993: 1098-9, fig. 46-7, Coralini 2001a: no. P.064.

48 On Antiphilus' work: Plin. HN 35.114. Pape 1975: 185-6, Ritter 1995: 134.

49 LTUR IV 1999: 141-5 [C. Lega], Lauter 1980-1. 
in the Casa di Octavius Quartio was in any way reminiscent of them, beyond the bare topic. ${ }^{50}$ On Artemon's work he comments: ${ }^{51}$ Laomedontis circa Herculem et Neptunum historiam ('The story about Hercules and Neptune with regard to Laomedon').

According to Pliny, the Porticus Octaviae held another painting by Artemon, depicting Heracles' apotheosis on Mount Oeta: ${ }^{52}$ Herculem $a b$ Oeta monte Doridos exusta mortalitate consensu deorum in caelum euntem ('Hercules, his mortality consumed by fire, going from Mount Oeta in Doris into heaven with the agreement of the gods'). It is the same event to which the second narrative strand in Room (h) builds, developed by following the hero's relationship with Deianira along the north, west and south walls of the room. Because of the poor preservation of the north wall, the sequence of events is disputed, in particular in the eastern part: Clarke agrees with Spinazzola in locating Heracles' apotheosis here; ${ }^{53}$ in contrast, Coralini follows de Vos and on the basis of narrative sequence places the episode convincingly in the western part of the south wall. ${ }^{54}$ In the eastern part of the north wall, she suggests that either an extended version of any of the adjacent two storylines was presented, ${ }^{55}$ or else a third Heracles adventure was on display, to complement the Iliadic cycle in the east and Heracles' end in the west; ${ }^{56}$ and on the basis of Ovid's sequence of Heracles' life, she suggests Achelous as potential subject matter. ${ }^{57}$

In the western corner of the north wall, three scenes document Heracles' encounter with the centaur Nessus: in the first, a nude male stands frontally to the viewer, his right leg slightly bent and set on a rock and his left arm outstretched towards the right. Coralini identifies this scene convincingly as the fight of Heracles against the centaur, ${ }^{58}$ an episode also recounted by Apollodorus and Diodorus Siculus. ${ }^{59}$ The hero's posture here matches his appearance in the five Pompeian depictions of this topic in the Third Style - not in every detail, ${ }^{60}$ but in the motif of the outstretched arm.

50 Disregarding the quality of Pliny's evidence, many scholars have seen the decoration in the Porticus Octaviae as the source of the decoration in the Casa di Octavius Quartio (see also above, no. 000): Schefold 1988: 196, de Vos 1993: 86, Ritter 1995: 134-6, Coralini 2001a: 165-6.

51 Plin. HN 35.139. See also Pape 1975: 185-6. $\quad{ }^{52}$ Plin. HN 35.139.

53 Clarke 1991: 204, following Aurigemma 1953: 975-1006.

54 Coralini 2001a: 167, following de Vos 1993: 86. $\quad{ }^{55}$ Coralini 2001a: 79-80.

56 Coralini 2001a: 87-8, 168-9.

57 Ov. Met. 9.1-273: Achelous, Nessus, death on Mount Oeta, apotheosis. cf. Croisille 1985: 94 no. 39.

58 Contra Clarke 1991: 204, who identifies it as the scene of Heracles on the pyre.

59 Coralini 2001a: 87-9, 167-8. Diod. 4.36.2-5, Apollod. 2.7.6.

${ }^{60}$ LIMC VI 11992 s.v. Nessos [F. Díez de Velasco], Ritter 1995: 204-7, Coralini 2001a: 87-9, Lorenz 2008: 222-4. Casa annessa alla Casa dell'Efebo (Regio I 7,19), Room (e), east wall; Third 
Heracles' means of subduing the centaur are sufficient to connect the depiction with this episode. ${ }^{61}$

In the second scene, around the corner on the west wall, Deianira receives the cloak from Nessus, ${ }^{62}$ the interaction between woman and monster a unique focus in the iconographic corpus of this myth. ${ }^{63}$ Deianira stands on the left, dressed in long garments and with a mantle on top. She holds a box with open lid, which the centaur on the right passes over to her, putting her in possession of the deadly garment that will seal Heracles' fate. The centaur is seen in three-quarter view and makes for the most impressive presentation of this type of monster in Pompeii, matched only by the depiction of Chiron from the Basilica in Herculaneum. ${ }^{64}$ In contrast to the devout but uncivilised creature shown in the other depictions of Heracles, Deianira and Nessus, the centaur is here given the features of a wise old man, set atop an elegantly defined horse body. Remarkably, the creature shows no signs of his imminent death, despite the literary sources, which place this episode after Heracles has despatched him.

The adjacent scene towards the left, again badly damaged, shows traces of a figure stoking a fire and of Heracles, seated on a pyre: this is a depiction of Heracles on Mount Oeta, with Philoctetes preparing the pyre, in the flames of which the hero will seek relief from Nessus' garment. ${ }^{65}$ No other versions of this scene exist in Pompeii, nor does what has been proposed as the final scene in this cycle (in the non-preserved western corner of the south wall), the hero's apotheosis on Mount Oeta, have any iconographic parallels in the town.

Surrounded by visual elements reminiscent of Hellenistic palace architecture, the Heracles frieze thus presents two sides of the hero's persona, each told as an independent narrative movement: towards the east, clockwise, Heracles performs as a public hero, sanctioning action and reinstating order; towards the west, counter-clockwise, a more

Style: PPM I 1990: 777, fig. 49. Casa del Centauro (Regio VI 9,3-5), tablinum (26), south wall; late Third Style: PPM IV 1993: 854-7, fig. 68, Lorenz 2008: 282-4. House Regio VIII 5,15-16, viridarium (b), west wall; Third Style: PPM VIII 1998: 574-6, fig. 2-3. Domus T. Dentati Pantherae (Regio IX 2,16), Room (e), west wall; Third Style: PPM IX 1999: 27-9, fig. 47. Casa di Iasone (Regio IX 5,18): MANN inv. no. 111 474; from Room (g), north wall: PPM IX 1999: 700-1, fig. 41.

61 See the scene from the Casa di Iasone (above n. 60).

${ }^{62}$ Croisille 1985: 91, Coralini 2001a: $167 . \quad{ }^{63}$ Coralini 2001a: 89.

${ }^{64}$ MANN inv. no. 9109. - Pagano 1990 and 2001, Croisille 2009.

65 Croisille 1985: 91, Coralini 2001a: 89-91, 167. Contra Clarke 1991: 204, who takes this to be a scene of Heracles and Deianira after the battle with Nessus. 
private aspect is shown, presenting the hero in relationship with his family and, collapsing the distinction between public and private again, his heroic death. This pan-vision of the hero's persona is for a Pompeian context as unusual as the iconographic means by which it is achieved, but in interaction with its companion piece, the Iliad frieze below, these oddities are turned into a particularly powerful mechanism to generate epic visions.

\section{The Iliad frieze}

The Iliad frieze, by virtue of its subject matter, forms part of a decorative heritage well developed in Roman painting. ${ }^{66}$ But this pedigree is thoroughly remodelled for its new context: the frieze may adhere anachronistically to the formal features of Second-Style epic friezes such as the one in the Casa del Criptoportico, but it shares few scenes with it. ${ }^{67}$ And while the Criptoportico frieze features Greek inscriptions, here they are in Latin, even if the spelling mistakes indicate that the labels were transcribed from a Greek source. ${ }^{68}$ Similarly, the frieze in the Casa di Octavius Quartio diverts from the content of the near-contemporary stuccoed frieze of the Fourth Style in the Casa del Sacello Iliaco, which yet again presents a different accentuation, exclusively focusing on the relationship of Hector and Achilles. ${ }^{69}$

The Iliad frieze takes its beginning in the south-west corner with the depiction of Apollo sending the plague into the Achaean camp (Figure 9.4): ${ }^{70}$ set in a rocky landscape, Apollo on the far right aims with his bow towards a figure already dead on the ground to the left, covered by a shield; further to the left, another figure is falling, caught by a second arrow. The rare situation tag written into the scene, 'LOIMOS' (plague), clarifies the god's action. In the Casa del Criptoportico, the same episode marks the beginning of the frieze, but the depiction is focused on an entirely different aspect: that is, supplication to the mercy of the god, ${ }^{71}$ and not on the punishment dealt out by him.

66 Aurigemma 1953: 974-1007, figs. 989-1051, Picard 1970: 80-1 pl. 55; PPM III 1991: 86-98, figs. 68-84.

67 Croisille 2005: 154. The selection of scenes in the Casa del Criptoportico puts considerable emphasis on personal relationships among the Trojans, the community of the Achaeans, the duels and the involvement of the gods.

68 Badius not Balius, Lykaon not Lycaon, Patroclos not Patroclus: Spinazzola 1953 vol. II: 1007, Ling 1991: 112, Croisille 2005: 154-5. See also Thomas 1995.

${ }^{69}$ See above n. 22. $\quad{ }^{70}$ PPM I 1990: 204, no. 18, Brilliant 1984: 62, Croisille 2005: 164.

71 Aurigemma 1953: 977. 


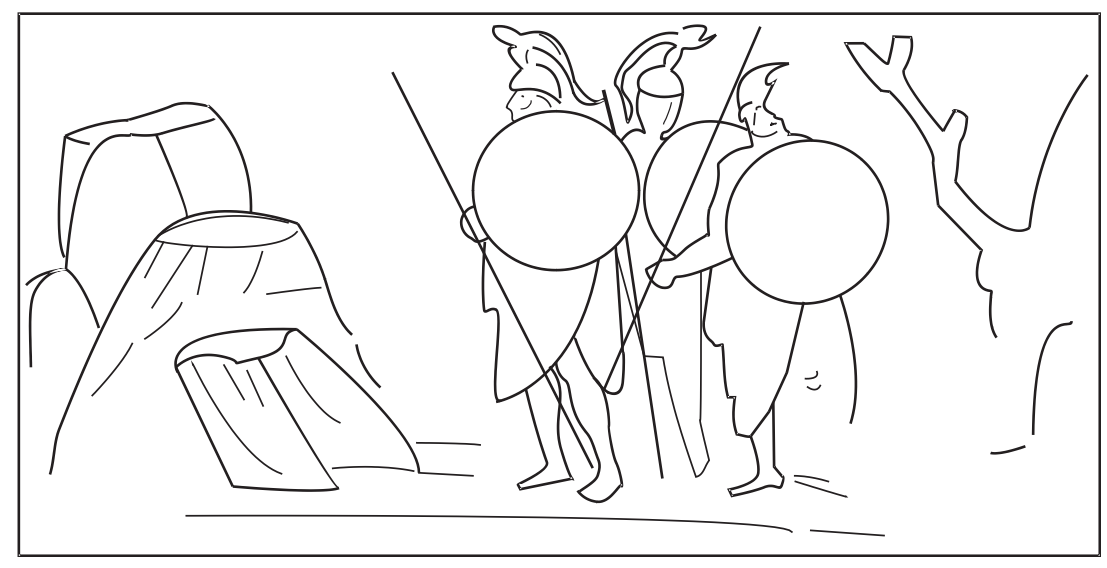

Fig. 9.5 Pompeii, Casa di Octavius Quartio (II 2,2). Room (h), Iliad frieze: Embassy to Achilles.

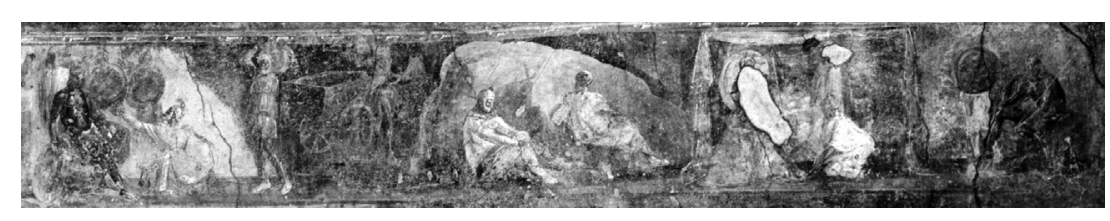

Fig. 9.6 Pompeii, Casa di Octavius Quartio (II 2,2). Room (h), Iliad frieze: In Achilles' tent.

The frieze continues initially on the opposite side of the doorway towards the garden, on the south and east walls towards the left. First, a boy is shown watering two horses. Spinazzola identified this episode, one not featured in Homer, as a cameo appearance of the two horses of Achilles which Peleus gave him. ${ }^{72}$ Given that the frieze features a pair of horses twice overall, and in both cases named as those Peleian horses XANTUS and $B A L I U S,{ }^{73}$ this reading is convincing. As an indirect reference to Achilles, they serve as an atmospheric overture for the three scenes to follow towards the left, presenting the embassy to Achilles as covered in book nine of the Iliad (Figures 9.5 and 9.6). ${ }^{74}$ In the first scene, Phoenix, Odysseus and Telamonian Ajax are shown on their way to Achilles' tent (Figure 9.5). The group is depicted in contained fashion, with groups of rocks on either side serving as a frame, and the three ambassadors are all heavily armed with large shields, helmets and spears.

\footnotetext{
72 Aurigemma 1953: 978-9.

73 In the second occurrence, only the name label for Balius (Badius) is extant.

${ }^{74}$ Hom. Il. 9.5.182-91.
} 


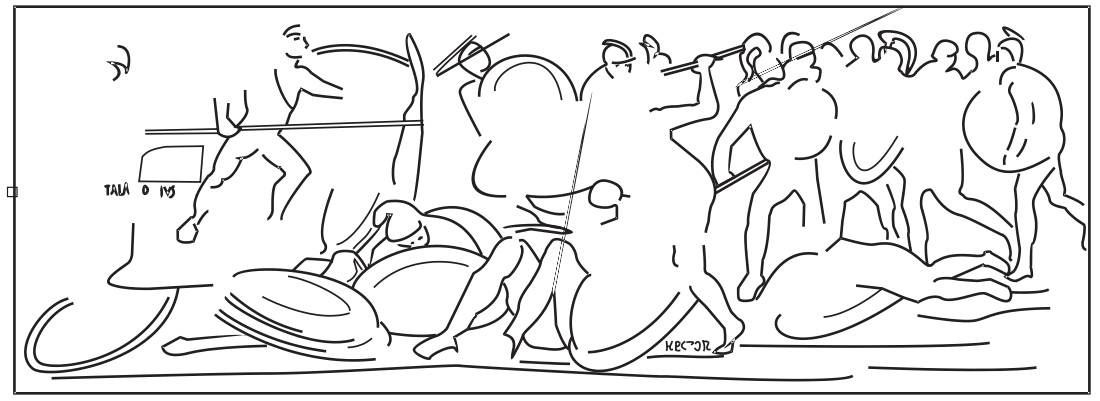

Fig. 9.7 Pompeii, Casa di Octavius Quartio (II 2,2). Room (h), Iliad frieze: Battle at the ships.

Following on the southern part of the east wall, the two other scenes of the embassy episodes zoom in on Achilles' tent, in each instance indicated by drapery borders (Figure 9.6): in the first, the nude Achilles sits on the right in a thoughtful pose, a sceptre in his left hand and his sword leaning against his seat, a fully armed Patroclus next to him. In the second scene, the embassy has reached Achilles, now sitting on the left, the sceptre still in his left hand and a shield at his back; Phoenix kneels in front of him, his two companions behind him.

From here, the frieze changes its direction to continue across the room on the west wall with two extended battle scenes, approximating to events in Books 12 to 15 of the Iliad. In the first half of the wall, the Teichomachia is presented with three battle groups of two combatants, in each, a dead body on the ground. The figures are all dressed in short tunics and bushy helmets, and they fight with spear and shield. Two warriors are named as DANAUS and LYKAON.

The second half features Hector's advance against the Achaeans in the battle at the ships. This composition differs considerably from the other battle scene: the foremost line of the depiction is filled with dead bodies and large shields, indicating further casualties; a large mass of combatants fills the right of this section, all geared up as before, but without clearly distinguishable battle groups. Only two characters are singled out by composition and name labels: in the centre of the scene, surrounded by bodies and other warriors, Hector is fighting towards the left, shaded against the viewer by a large shield. His opponent is a nude warrior, AIAS TALAMONIUS, who stands on the left in an elevated position in front of a ship, not surrounded by any other combatant and with his body opened towards the viewer (Figure 9.7). In a presentation emulating 


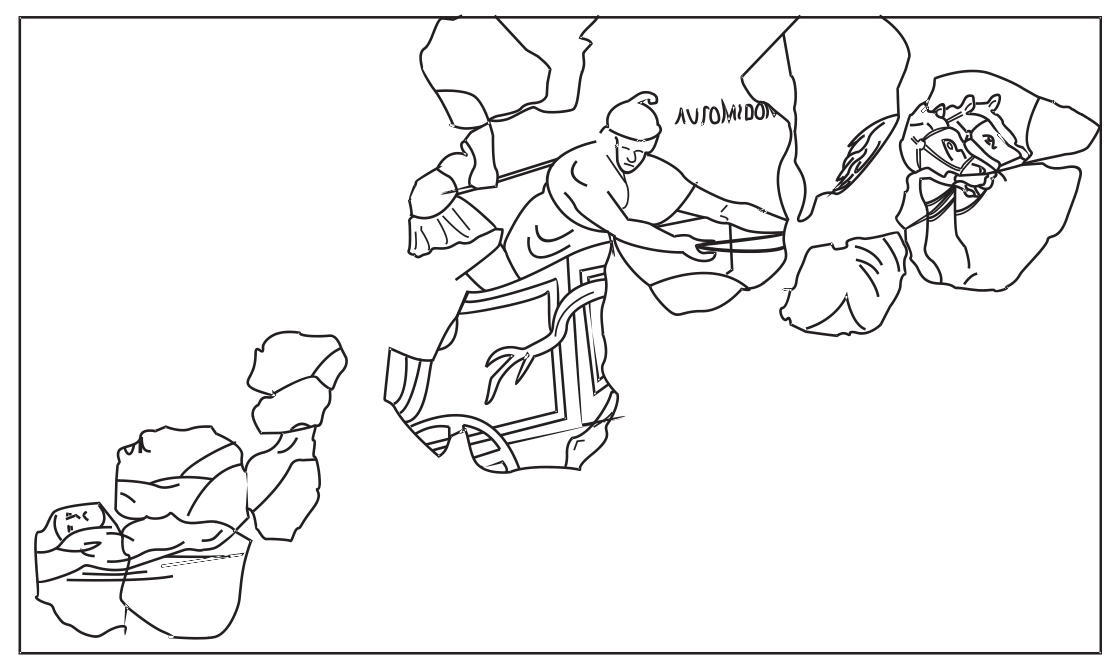

Fig. 9.8 Pompeii, Casa di Octavius Quartio (II 2,2). Room (h), Iliad frieze: Hector's body.

Homer's account in Book 14, Ajax is charging with spear and shield towards the right.

Spinazzola was the first to identify the next scene around the corner on the north wall as the retrieval of Sarpedon's body, reported in Book 16: ${ }^{75}$ three Trojans clad in oriental garments carry what must have been a body. ${ }^{76}$ The reading is supported by the fact that the character causing Sarpedon's death, Patroclus (PATROCLOS), is depicted charging into battle in the scene adjacent to the right. ${ }^{77} \mathrm{He}$ is dressed in a short tunic, armed with spear, shield and helmet, and both he and the two horses drawing his chariot are identified by name labels. They are charging to the left over a pile of shields and a dead body.

Further to the right, Thetis is about to hand over the new shield for Achilles, as reported in Book 19: the goddess is identified by a name label (THETIS), and so is her son (ACHILL[ES]), whose figure is not preserved. Another cameo appearance of Achilles' horses creates a pause before he is in the adjacent scene shown with Automedon (AUTOMEDON) in a four-horse chariot, dragging Hector's corpse around the walls of Troy (Figure 9.8). The mutilation of the Trojan's body finds a parallel in the

\footnotetext{
75 Hom. Il. 16.462-82.

76 The remains of an inscription identify one of the characters as] YKES.

77 Aurigemma 1953: 990-1.
} 
Casa del Sacello Iliaco, even if Achilles is shown jumping on to the chariot, while in Room (h) he is already standing on it, poking at the corpse. ${ }^{78}$

Returning to the east wall, the frieze reaches its climax in two extended scenes (Figure 9.3). First, the funeral games for Patroclus are depicted. The episode begins with the presentation of Patroclus' body on a bier, to be followed by the chariot race, with three two-horse chariots (Diomedes, Menelaus, Antilochus) racing around attendants indicating the turns. ${ }^{79}$ The charioteers are all dressed as warriors, and they are watched by figures in the background. It follows a group of boxers fighting each other, dressed only in loincloths. The second and final visual is devoted to Priam's plea for Hector's body: first, back in Achilles' tent in another scene paralleled in the Casa del Sacello Iliaco, ${ }^{80}$ the Trojan king kneels in front of the Greek hero, while another Trojan brings gifts from a cart parked nearby (Figure 9.7). Achilles sits dressed in a mantle, with his right hand on his shield, accompanied by a group of Achaean warriors in the background. Then, Priam is shown on his night watch, in a rocky landscape and accompanied only by Ideus.

While formally in line with other Roman frieze depictions of the Iliad, that in Room (h) establishes specific 'hot spots' by means of its S-shaped distribution across the room and its strong emphasis on the persona of Achilles, in particular, with the amassing of scenes set in or around the hero's tent on the east wall, marking the beginning and the end of the ring composition in which the Iliadic material is displayed. While the warriors in the Iliad frieze are all heavily clad in armour, Achilles is - like Heracles shown with an emphasis on his physicality, at least in the scenes in the tent. However, unlike Heracles, Achilles is the same size as all the other figures in the scene, and there is no reference to his private persona: his actions are all linked to the war, even the scenes in the tent and with his mother.

\section{Heracles on top of Troy}

Vitruvius regards the Homeric epics and their telling of the fates of Troy as a particularly appropriate topic for domestic painting. ${ }^{81}$ With its combination of the Iliad and Heracles' adventures on Trojan shores, the design of Room (h) seemingly follows the architect's advice. ${ }^{82}$ The figural decoration

\footnotetext{
78 Also note part III of the introduction.

79 Two of them might be engaged in another sport: Aurigemma 1953: 1000-2.

80 Aurigemma 1953: 894-6. ${ }^{81}$ Vitr. De arch. 7.5.2-3. Brilliant 1984: 60, Clarke 1991: 207.

82 Tybout 1989: 55-108 provides a critical analysis of Vitruvius' opinions on wall painting.
} 
of the room displays considerable efforts to reappropriate the life of Heracles as an epic subject, in its formal appearance, as a frieze, and in its rare focus on his involvement in Trojan matters; in addition, it unites the two most popular heroes on the walls of the Campanian domestic sphere, Heracles and Achilles, around Troy. ${ }^{83}$ But it would be a mistake to discount the design simply as the result of a tense petit-bourgeois attempt at ticking the boxes of fashionable upper-class living - as a concoction of dated standards and mainstream crowd-pleasers.

Room (h)'s decoration would doubtlessly elicit a series of vitriolic comments from Vitruvius, not least because of the scaenae frons, the wall turned cinema, and the split screen, with the two friezes and the contrasting concepts of technical space behind them. Yet it is a mark of the innovative character of the decorative choices made in this room that these bones of contention serve as the creative foundations of what is on display and the epic visions it creates.

At the core of the design is the fact that the two friezes, the two 'reels' of the split screen, take different directions through the room: the Heracles frieze starts in the north-east corner, branching out left and right, to end either side of the opening on the south wall; the Iliad frieze commences in the corner diametrically opposite, in the south-west, advances south-east, and then crosses the room, to develop from the south-west back to the south-east. This distribution introduces another layer of differentiation between the two friezes on the level of technical space, with regard to the friezes' linear extension: the Heracles frieze is arranged, forcing the viewer to choose which aspect of the hero to explore; in contrast, the Iliad frieze is shaped as a ring composition centred around Achilles' tent, thus mapping visually a central characteristic of the Homeric epics.

These two different spatial frameworks are matched by differences in the internal arrangements of each frieze, with regard to the length of individual episodes, their complexity and the moment of action chosen. In the Iliad frieze, extended scenes alternate with shorter clips, not at all unlike Homer's own technique of storytelling: the two battle episodes on the west wall and the funeral games for Patroclus on the east wall take up a long stretch of frieze, inviting the viewer to pause to explore the tableau of dynamic action in detail; the short scenes on the south and north walls of Apollo, Achilles and Patroclus spur the viewer on to follow the narrative and connect with its lead hero, Achilles.

83 Schefold 1954: 114, Leach 2003, Coralini 2005. For Hercules in Herculaneum, see Pagano 1990, 2001, Pappalardo 2001. 
The figure of Achilles is further pushed into the limelight because the episodes set around his tent are displayed with enhanced complexity: the embassy comprises three individual scenes, Priam's visit, two. This narrative micro-perspective in the south-east corner of Room (h) affords a type of viewing different from the extended mono-scenes in the west and east: while the latter draw the viewer's attention to the depiction, the former seem to invite the viewer to compare the build-up of the episode on display with that known from the Homeric epic, perhaps even to recite a couple of lines while following the frieze.

As far as the fragmentary nature of the Heracles frieze allows for an assessment, the distribution of episodes and scenes subscribes here to a different, more symmetrical concept, without alterations with regard to audience participation or any apparent negotiations between the story as it is visualised, and what is memorised about it. Each scene occupies comparable amounts of space, and all episodes are subdivided into groups of two or three scenes. Put together, these individual episodes form distinct storylines, only connected by their protagonist, Heracles: from the northeast to the south-east, the future of Troy, and Heracles' end from the north-west to the south-west.

Another key characteristic of the Heracles frieze is its focalisation. While the Iliad frieze features scenes leading towards or away from a moment of decisive action, such as the embassy scene or Priam's night watch, the Heracles frieze zooms in on the climactic moments: the argument with Laomedon, the marriage of Hesione and Telamon, the crowning of Priam, the presenting of the robe, the burning on the pyre. This difference arises from the differing formal and iconographic templates at the core of each frieze. But regardless of the origin of the difference, its effect is that the scenes of the Heracles frieze are accentuated in their portrayal of a clearcut finality, not least because, constrained by its layout in the room, Heracles' story cannot go around in circles.

The two friezes, each on their own, form coherent narrative units. The Iliad frieze is driven by a detail-rich stringency, despite its awkward arrangement across the room. It leads its viewers to a point of closure, thereby presumably displaying the qualities that rendered a Homeric frieze in Vitruvius' eyes particularly suitable. With its divergent arrangement, and its two points of closure, the Heracles frieze lacks this type of homogeneous flow and instead concentrates on the condition, not the process, of heroic accomplishment.

Yet the existence of the two friezes on top of each other, on the splitscreen stage of the patchwork scaenae frons in Room (h), challenges the 
isolated, 'freeze-framed' qualities of each. As already probed with regard to distribution and focalisation, their joint appearance facilitates comparison, which in turn, by means of deconstruction, can have considerable repercussions for the operative effect and content of each frieze. The different directions of movement - a feature uncontested, no matter which scenes appeared in the north and south of the Heracles frieze form the starting point to unravel the interactivity between the two friezes and assess their effect on the content of each individually, and the room as a whole.

The competing routes of the friezes blur the focus points and narrative sequences constituted in each frieze, and so frustrate a viewer; equally they may open up entirely new insights into the two storylines on display: to follow the Iliad, viewers coming from the peristyle would have to move along the south wall towards the east. En route, they would encounter the embassy episode and Heracles' apotheosis, then Priam's investiture and Telamon's marriage with Hesione. Turning their back on the embassy episode, they would continue on the west wall, encountering en passant the death of Heracles, then Nessus and, finally, the Laomedon episode, to find closure in the marriage of Telamon and Hesione; his scene would feature twice along the route of the Iliad frieze, serving as a canopy on top of Priam's night watch and Phoenix's proskynesis in Achilles' tent.

When following the Heracles frieze from the north-east corner, two routes are on offer, towards Heracles' apotheosis or Priam's enthronement. In both cases, the death of Hector would be the first visual of the Iliad frieze. Towards the west, en route to Heracles' end, the viewers would then retrace the steps that lead towards the end of Hector; towards the east, in moving up to Priam's kingship, they would additionally encounter the king's supplication, as an indicator of another shift in power.

In their unlikely partnership, the two friezes stimulate a form of comparative viewing that to its audiences must have felt as disturbing as the mock scaenae frons layout of the wall overall - the presence of the two friezes where there should be a stage or perhaps an aedicula with a mythological panel, and the differing concepts of technical space at the heart of each frieze, each conjuring a distinct illusionism, a clash of competing metaphorical spaces.

But it would have been productively disturbing: wall painting in the Neronian age saw an increased interest in the exploration of the mathematical dimension of spatial representation and its connection with the creation of meaningful relationships between objects, an interest in non-homogeneous space to overcome the dichotomy of reality 
and artificiality and create pervasive and hence particularly gripping narratives. ${ }^{84}$ The design of Room (h), indeed of the whole Casa di Octavius Quartio, is particularly devoted to this interest, and it reads as a virtual manual to the lack of homogeneity in shaping a distinctive form of visual narrative.

The deconstructive power of the double frieze, while dismantling the narrative continuum of each individual frieze, produces new storylines and opens uncharted territory for a metaphorical or allegorical viewing of what is on display. And it is with the opening scene of the Iliad frieze in the south-west corner of the room, the first seen by audiences approaching from the viridarium, that this process of double-platform narration begins: Apollo spreads the plague in the Achaean camp, an operative element crucial to the further course of the Iliad. Equally, it is not without relevance for the Heracles frieze: Heracles' rescue of Hesione is obviously only necessary because of Laomedon's obliviousness towards Poseidon and Apollo, causing the former to send the sea monster, while the latter inflicts a bout of plague on Troy.

The motif of Apollo sending the plague, therefore, serves to connect the two friezes, welding their storylines around an element of divine punishment, accentuated as it is here. This pivotal role of the scene could also explain why the rare situation tag is used here, with the word 'LOIMOS' lifting the scene out of its immediate context inside the Iliad frieze and interweaving it with the events in the north-east corner of the upper frieze. On entering the room from the viridarium, viewers are instantly introduced to a visual that establishes the two friezes as each other's referential guide.

The powers of the plague spread even further. First, in its initiatory role in the two friezes, the scene confounds any prior assumptions about their sequence. Strictly speaking, Heracles' Iliadic adventure forms the prequel to the Iliad; here however, both storylines come together in some sort of infinite ring composition that would suit a Tarantino plot, from a director fond of the 'split screen' mode of visual narrative to convey convoluted plots: ${ }^{85}$ the plague that causes Troy's demise is the same plague that leads to the castigation of its evil king; to a new king, invested by a Greek hero; to the demise of Troy by another Greek hero. ${ }^{86}$

Second, in its combination of text and image the scene demonstrates that the whole decoration is based on the understanding that the

84 Lorenz 2013. $\quad{ }^{85}$ Jackie Brown (1997); Kill Bill: Vol. 1 (2003).

${ }^{86}$ For the Roman perspective on the immorality of Troy, as conveyed in the Iliad (e.g. the Aeneid and the historic Trojan violation of bargains with gods / hospitium), see Coffee 2009: 39-66. 
relationship between the two media at the core of the design is dynamic, since both have the means to generate or deconstruct, tell or illustrate, and open or close association: the situation tag might tell the audience what the scene is about, while the depiction of Apollo illustrates it; but the tag also breaks up its own narrative, by illustrating the link with another narrative, leaving the painted Apollo to get on with the job of telling the Iliad. A nightmare for Lessing's disciples, ${ }^{87}$ this intermediality enhances the immersive qualities of what is on display and draws the viewers into the action.

But why do it with these two subjects specifically; with an epic in combination with a storyline, the epic-ness of which is not confirmed? The Iliad frieze, the narrative sequel to the events around Heracles, is here literally presented as a foundation myth of, if not as a visual aition for, the Heracles scenes. This is mainly achieved by the formal arrangement, the position of the two friezes in relation to each other, the stylistic traditionalism of the Iliad frieze, and its seemingly more profound coherence; all obviously further helped by the scene of the plague, setting off Heracles' Iliadic cycle. It is as if by aligning Heracles with the Iliad, the epitome of all epic, Heracles' own status as a hero of epic standing is legitimised. The visuality of the room, therefore, with its style and the strategies of transmission employed, provides the scenes of Heracles with what is necessary to belong to the genre of epic.

The epic veneer suits Heracles well, given that he is the mythical founder of Pompeii, and generally the model hero of Campania. ${ }^{88}$ Elevating him to the level of an epic hero also enhances the status of the city and, by the same token, of the inhabitants of the Casa di Octavius Quartio. And the iconography of the frieze confirms such aspirations, for it presents Heracles within the framework of archetypal patterns of regal behaviour: he negotiates, he fights, he blesses man and wife, he appoints kings, he is burned on a pyre (just like Patroclus and Achilles), and he ascends to divine status.

In addition, the cast of the Iliad frieze provides an audience for the events in the frieze above, orchestrating and accentuating them, not unlike the arrangements in some Julio-Claudian state art, such as on the Gemma

87 See Giuliani 2003 for a critical discussion of Gotthold Ephraim Lessing's influential position on the relationship of text and image and his claim that only the former has the potential to narrate, the latter to illustrate.

${ }^{88}$ Solinus 2.5: ... ab ipso (Hercule) in Campania Pompeios, quia victor ex Hispania pompam boum duxerat. See de Vos 1993: 89. Herculaneum is even more obviously linked to him as mythical founder. 
Augustea or the Grand Camée de France, where the representation of the imperial family relies on depictions of defeated barbarians in the register below. ${ }^{89}$ This is most noticeable at the point where the two strands of the Iliad frieze re-join, in the scenes of the embassy to Achilles and Priam's supplication in his tent: internally, as part of the Iliad frieze, these scenes connect two seminal events of the Iliad by means of mirror images and thus confirm Achilles as the central protagonist of the frieze; externally, they exude a rhetoric of power and honourable subordination, generating a fitting framework for Heracles' officiating behaviour above, where he reinstates proper leadership in Troy. In the same way, the chariot race at Patroclus' funeral, with its praise of equestrian skill, enhances the dimension of Heracles' negotiations with Laomedon above, for they concern the horses of Tros. And the extended battle scenes in the lower register of the west wall generate an atmosphere of fierce desperation to provide a suggestive backdrop for the tragic events around Heracles' death above.

The double-frieze banding triggers processes of comparative viewing; within these, each scene can easily become a crystallisation point of symbolic signification, pointing beyond what is on display. The pictures thereby work as generic visuals, celebrating (and scrutinising) male virtus, the matrimonium, or the components of just leadership. Hence the double frieze cannot only overcome the genres of literature, by turning myth into epic, but also the limits between myth and the mundane sphere of daily life in front of the pictures, morphing into a point of reference for the selfimage of the dominus and matrona of the house.

This type of allegorisation, facilitated by the strategies of display, constitutes a truly Roman feature. But then again it differs from the selective approach towards emulating Greek myth that characterises contemporary displays of mythological stories in Pompeii: the combination of friezes may reflect the usual pragmatic accentuation of mythological material towards key issues of life outside the picture but their separate frames still preserve the fictionality of the individual narrative and reinforce their standing as epic rather than as an exclusively allegorical visualisation. This framing manifests the unease, almost reluctance, so characteristic of Pompeian mythological decorations of this period to resolve the dichotomy between myth and vita Romana. ${ }^{90}$

89 Gemma Augustea: Brendel 1939, Simon 1986, Megow 1987: 133-63, Scherrer 1988, Pollini 1993. Grand Camée de France: Simon 1967-8, Jucker 1976, Megow 1987: 78-80, Giuliani 2009.

90 Lorenz 2008: 246-58, 447-50. 
A comparison with the 'split screen', the cinematographic mode that came into fashion in the $1950 \mathrm{~s},{ }^{91}$ helps to define further the mechanisms which steer the decoration in Room (h). In 'split screen' mode, the different frames are displayed simultaneously, blurring the distinction between the inside and the outside of each frame, while preserving each individual area. This produces a range of ambiguities on the level of spatial and temporal alignment: what is displayed simultaneously does not necessarily take place at the same time and in the same place, yet the viewers have little at their disposal to discern any discrepancies. Rather, they are put in an unstable, even frustrating relationship with the split screen; but one which can generate immediate and unstructured association and dynamic forms of narration, hence the popularity of the 'split screen' technique in advertising and in film sequences geared towards condensing complex relationships, be they narrative, situational or emotional/ atmospheric.

These characteristics of the 'split screen' help in pinpointing the difference between the usual Pompeian Fourth-Style arrangement of mythological paintings, where three or four panels adorn the walls of a room, and the set-up in Room (h). Both arrangements allow for storylines and associations to build up between the pictures. But the immediacy generated in the decoration of the room in the Casa di Octavius Quartio is unbeaten, because of its seemingly continuous alignment that on closer inspection gives way to an intricate network of references and sub-plots, and its accomplished mastery at functionalising every single component, no matter whether formal or iconographic. This decoration is playful and discursive, complex and individual: recognition of this should once and for all confound any notion that it simply served the function of an imperial panegyric, as a copy of a metropolitan Roman design. ${ }^{92}$

\section{'Split screen' epic and epic visions}

The 'split screen' design of the walls in Room (h) of the Casa di Octavius Quartio stimulates an intense comparative game, with an infinite number of variables for interaction. These guide the viewers through the room,

91 Talen 2002, Friedberg 2006: 192-239.

92 The decoration of the Domus Transitoria has been taken to be influenced by the considerable ideological standing of the story of Heracles, Priam and Laomedon for Nero, in order to legitimise his succession from Claudius (de Vos 1990); and Vespasian used Heracles' divine apotheosis as a key identifier (Schefold 1954: 137). 
through different storyscapes, spatial and temporal, and across different genres and levels of meaning. The design of the scenes in the room proves that those behind the decoration were familiar with the Homeric Iliad as a text, ${ }^{93}$ and possibly with discussions around the epic character of Heracles. But this obvious familiarity is not functionalised to construct a dominance of the textual over the visual. On the contrary, the proficiency prevalent in the design, which plays to the strength of each medium, is the launch pad for a truly immersive transmission of content.

In principle, one could imagine a Pompeian 'split screen' design that would work without an epic pedigree. But given the lack of any such example, it is clear that for those in charge of the decoration in Room (h) epic-ness added value: it enabled those viewing it to see aspects of life in an epic light, not just the life of Heracles, with his semi-epic standing, but also their own, non-epic existence. The qualities embedded in the category 'epic' here elevate what is on display to a level of established, undisputed validity, while providing the means to break the content down to fit the affordances of acts of entirely individual symbolisation.

Retracing the steps of the viewers helps to define the individual components of the epic visions created by the visualisations in the room, epic and otherwise. First is the element of continuous narrative, supported by the sequencing of scenes and textual labels: rare in Pompeii at the time, it makes for a digestible, albeit hearty, narrative offering and provides epic veneer, even for a storyline not belonging to the genre. Hence on this level, visualisng epic is about the provision of a familiar storyscape to snare its viewers, and any epic visions are fuelled by a desire for comfortable, even if slightly dated entertainment.

This same component is further enhanced on the second level: both friezes, as depictions of epic and epicised material respectively, embody along with the surrounding decoration luxury items and evoke the lavish decoration of Hellenistic palaces and grand Roman villas. In a room looking on to an Egyptianised landscape garden able to compete with any Hellenistic park landscape, visualising epic on this level is about status; any epic visions here are fuelled by notions of a glorious Greek past and luxurious Hellenistic ambience.

On a third and final level, all this splendid cosiness is reappropriated as machinery for something completely different, gaining its thrust not least

93 There are differences from the Homeric text, but the representations draw on the general Greek iconography for the Iliad: Aurigemma 1953: 977-1002. 
from the discrepancy between the old-fashioned appearance and the cutting-edge arrangement. Facilitated by the split screen, the visualisation of epic here is about deconstructing the narrative and overcoming the boundaries of genre, even those between fiction and reality; with the added benefit that an epic frieze offers a particularly well-stocked arsenal of transmission techniques and well-established templates to generate powerful visions. The outcome is epic visions full of abstract values and ideals, such as wealth, tradition and superiority, virtus and matrimonium. While gaining their power from their epic lining, they are essentially dissociated from the epic content and function no differently from other contemporary mythological pictures.

From this Pompeian perspective, with its careful layering of intra- and interpictorial and intertextual components, to visualise epic and to stimulate epic visions produces a particularly playful, far-reaching, yet notably exclusive visual offering. Exclusive it may be, but this luxury makes it perfectly suited to serve the hunger of the Neronian and Flavian period for a boundary-crossing, all-encompassing, immersive intermediality. 